\title{
Gestalt-Prophetic: The Parenting Method for Early Childhood with Gadgets Addiction
}

\author{
Wahyu Kusumaningtyas, Ikhwan Aziz Q, Nur Laili, Sri Hartati ${ }^{1}$ \\ Institut Agama Islam Ma'arif NU (IAIMNU) Metro Lampung, Indonesia \\ @ srihartati2191@gmail.com ${ }^{1}$
}

\begin{abstract}
Article Information:
Received December 31, 2018

Revised February 19, 2019

Accepted May 6, 2019
\end{abstract}

Keywords: gestalt-prophetic; parenting; gadgets addiction

\begin{abstract}
This study was conducted to determine the significance Gestalt-Prophetic on improving parent awareness on parenting method for early childhood with gadget addiction case. This quasi-experimental study was carried out by involving two groups of parents $(N=74)$ which divided into two groups, control $(\mathrm{N}=38)$ and experiment $(\mathrm{N}=36)$ group. This study uses the scale of parenting behavior ( $\alpha=0.525$ ) referring to the theory proposed by Baumrind (2005). T-test was used to determine the significant differences between both control and experiment group. The control and experiment group have significant differences after receiving treatment and the increase of mean showed that G-Pro is effective to improve parent awareness on parenting method for early childhood with gadget addiction case. The both educational $(t=-2.20, p=<0.05)$ and vocational $(t=2.50, p$ $=<0.05$ ) background showed difference mean and standard deviation. The mean between control and experiment group based on educational background showed the highest difference is senior high school and the lowest is elementary school. Then, mean based on the occupational background the highest difference is entrepreneur and the lowest is teacher.
\end{abstract}

\section{INTRODUCTION}

Family is the smallest unit in the community where members get protection for peace and development of their souls. This function creating consequences for parents which is consisting of husband or father and wife or mother. This is leading the children to think who will later replace the role of their parents (Soekanto, 2004). The presence of the family is very important for the psychological development of the child. The family is a primary source in determining the level of intelligence and intellectuality of children, both in terms of moral, ethical, aesthetic, moral, social, and emotionally (Hartati, 2017).

Parenting is the attitude of parents in interacting, guiding, fostering, and educating their children in daily life to make children successful in their life. Parenting has a definition that the process of education provided by parents to children through continuous and deep interaction, it aims to provide a picture to children through attitudes and behavior in guiding and directing the development of children, therefore, children can grow into a responsible individual (Djamarah, 2014; Gunarsa, 2007; Jannah, 2012; Sunarti, 2004).

Helmawati said there are four types of parenting that are often applied in the family (Helmawati, 2014), those are authoritarian (parent-oriented), permissive (children centered), democratic, and situational parenting. Whereas, another finding stated that parents interact through several ways like authoritarian, authoritative, neglectful, and Indulgent Parenting (King, 2010). Every parent certainly tries to give the best for their children. However, 
sometimes parents did not realize the parenting method they are doing is actually wrong and has a negative impact on children (Anna, 2018). The parents then and now are different. The difference triggered by the presence of external factors like the development of technology which is signed by the existence of various types of gadgets with different brands and featured the latest applications. The difference in parenting affects the behavior of children. For instance, children then who had not familiar with gadgets are enthusiastic to play with other children to establish a social relationship. Nowadays, the presence of gadgets, their focus is more to virtual games. Furthermore, children's behavior tends to be individualistic, inevitably, the social relationship getting weaken.

The issue stated above should be attention to parents. The role of parents in providing open and communicative guidance for children are parents main role, with open and communicative guidance parents can control what children do and sees, this is a form of preventive action to avoid the negative impact of using gadgets (Warisyah, 2015). The open and communicative attitude of parents is needed in providing supervision for every activities child does when playing gadgets. In addition, there should be limitations in accessing certain features and the need for particular methods to reduce and avoid children from using gadgets.

The negative impact caused by electronic media is not only in adults but also in children. Those effects of using the gadget include inhibiting children's emotional intelligence and addiction (Santoso \& Sutanto, 2013). Gadgets addiction can affect children's brain development because excessive production of the hormone dopamine disrupts the maturity of the cortex's prefrontal function, which controls emotions, self-control, responsibility, decision making, and other moral values. Addiction to gadgets can cause attention-focus and hyperactivity disorders (Setianingsih, Ardani, \& Khayati, 2018).

A gadget is a tool used by people who have an interest in school, college, and work. However, the fact is that the use of gadgets has become dominant in nowadays children's lives. Ironically, gadgets are not foreign items for early childhood, which in fact they are not yet feasible to use. It also starts with parents who are careless of the positive and negative effects of gadgets for children.

This often happens around us. For instance, when a mother busy with her work, instead of being able to give her child treatment she gives gadget for her child. However, this kind of routine resulted in a feeling of addiction to children. It seems that children are also able to understand vocabulary very quickly with the use of gadgets such as children easily able to download game applications, moreover able to choose interesting videos on the youtube.

Based on the results of preliminary observations, two out of ten mothers or parents gave a statement that they were not aware of the impact that children had on the use of gadgets. As mentioned earlier, EP (initial name) considers gadgets to be a friend for children, early childhood should play with their peers, socialize with people around them, explore themselves, and think creatively in addressing problems.

This situation has to obtained attention because all the time with electronic equipment means reducing the time face to face with parents and another family member. When we take secondary rules in the children perspective, parents begin to lose power, and the prevailing culture becomes its successor. Children will be more vulnerable to external pressure; children tend to rely on someone other than parents to guide them and prefer to adopt other values (Borba, 2010).

Parental guidance and the advisory is needed to avoid negative impacts on the utilization of gadgets. The guidance can be a tool to establish communication between parents and children in order to internalize the use of gadgets (Musthafa, 2017). Lack of parent awareness on giving parenting to children the importance of early stimulation on early childhood development and the impact that children will receive regarding advanced developments (Setianingsih et al., 2018). 
In response to this issue, there is a need for a guidance and counseling approach, the approach that will be used is Gestalt-Prophetic (G-Pro). This approach is the result of a critical analysis conducted by Imas Kania Rahman on the Gestalt approach of Frederic Perls (Rahman, 2018). G-Pro is a best practice with the concept and practice of a sufistic approach to counseling and guidance by combining group guidance and individual counseling approaches. This approach integrated into guidance and counseling service for the development phase of adolescents, adults, and the elderly with a variety of psychological problems. Particularly related to the inability of individuals to integrate their thoughts, feelings, and behavior because they experience a gap between present and future; the occurrence of conflict between strong positions or top dogs that demand oneself and the state of self-defense, helpless and passive or known as underdogs; experiencing a gap between present and future; escape the reality; there is a conflict between social demands and biological readiness (Rahman, 2017).

The basic assumption of the Gestalt approach about humans, in general, is individuals can overcome their own life problems, particularly if they use awareness of experiences that are being experienced (Komalasari, 2014). Therefore, in relation to the values contained in the prophetic term illustrates that each individual to raise awareness is needed to increase their faith and piety in accordance with the religion they adhere to. In addition, understanding of religion also proves evidence of gratitude for the nature that God has given to humans (Hartati, Latipah, \& Maba, 2018).

Some studies explained in reducing the negative impact on the gadgets use, indeed the role of the family is needed, particularly father and mother, is immensely important for early childhood. It is important to apply communication patterns or dialogue interactively. In addition, permissive parenting is sought not to be applied in parenting due to will increase the behavior using gadgets. Parents are a reflection of their children in behavior (Musthafa, 2017; Palar, Onibala, \& Oroh, 2018; Warisyah, 2015; Wijayanti \& Akbar, 2018; Wulandari \& Ristiawanti, 2018). Furthermore, not much study was conducted to investigate gestalt in improving parent awareness on parenting method. For example, Trijayanti, Nurihsan, \& Hafina (2019) were the investigation of the effectiveness of gestalt to reduce guilt. The authors have found a study about gestalt for the parent to improve the psychosocial of children (Brink, 2009), but this study focused on the children instead of the parent. In the other hand, Rahman $(2017,2018)$ provides the guidelines to conduct the approach and still needed more study to prove the effectiveness and impact of this approach. The author found only one study follow up the guidelines and investigated the impact of G-Pro on students' self-awareness (Fitriawati, 2019).

Therefore, in this study authors decided to conduct the follow-up study due to lack of information about the effectiveness of G-Pro in solving problems, particularly in improving parent awareness on the method of parenting. Authors used the Gestalt-Prophetic (G-Pro) approach as an initial alternative to establishing awareness in early childhood parents. The concept of awareness applied is full awareness, full contact, and full support. These three concepts referred to the nature of consciousness, contact, and support in Islam. The first step that needs to be done is to established awareness of parents regarding the parenting method that has been or will be given. Remind whether as a parent can be responsible for the problems that have occurred (mistakes on parenting) by applying the concept of awareness in the context here and now as the main focus, thinking about everything that happens will have an impact on future of child development. Thus, parents need to obtained guidance as a preventive effort and counseling as a healing action against mistakes in parenting for children.

This study main goal of this study is to examine the effectiveness of G-Pro to improve parent awareness on parenting method. The hypothesis of this study are as follows; 1) there were differences in parenting between the group treated with Gestalt-Prophetic (G-Pro) and 
groups that were not treated, 2) parents occupational influences the effectiveness of the G-Pro approach in developing parenting for gadget addiction in early childhood, and education background of parents influence the effectiveness of the G-Pro approach on establishing parenting in early childhood gadget addiction.

\section{METHODS}

In this study, the dependent variable is parenting on gadget addiction in early childhood and the independent variable is Gestalt-Prophetic (G-Pro). The treatment is deliberately given to influence the dependent variable. This study was conducted at Kindergartens of Metro City, Lampung, Indonesia with the consideration that authors found many issues about early childhood development. The author intends to use Gestalt-Prophetic (G-Pro), which is considered effective to established parenting method.

This study uses an experimental method, using random sampling as to selecting study sampling. The study was conducted in July 2018 - October 2018. Subjects (parents who have early childhood) involved in this study were 74 participants (36 experiment group and 38 control group).

This study uses the scale of parenting behavior $(\alpha=0.525)$ to see the achievement of results by referring to the theory proposed by Baumrind (2005). Examples of available statements are: "Do you give your child the freedom to use gadgets?"; "Do you obey your child's requests/wishes to use a gadget even though you think it is the wrong thing or not?". The aspects revealed in parenting are authoritarian, permissive, and authoritative parenting. Analysis of this data using the T-test, the independent sample T-test was used to examine the test results in the experimental and control groups.

The implementation of the G-Pro therapy is carried out in five stages, namely the identification stage, basic services, responsive services and reflection, the integration stage, final stage, and termination.

\section{The identification stage}

The purpose of the identification stage is to recognize the problem of parenting and see the suitability of the problem with the G-Pro. In addition, this stage also helps to prepare the equipment that will be used in the implementation of counseling from the beginning to the end. The activities carried out at the identification stage are identification of parenting for gadgets use in children; Cross-check the accuracy of identification with participants by extracting information from classroom teachers regarding the impact of parenting on the behavior of children in school; Establish the suitability of the problem with the respondent; Determine the schedule for the next meeting; Prepare the equipment needed.

\section{The basic service}

This stage is the step of strengthening the interaction between each individual in the process of guidance and counseling. In addition, at this stage equip the respondent with a deep awareness so that the counselee realizes the importance of being fully present in the context here and now, always maintaining full contact with self, environment, and God. The activities carried out at this stage are: Building participants' sensitivity through inner zones, middle zones, and outer zones; Applying the basic of group guidance services using SDBHSM cards; counselors give confrontational statements to participants in all sessions to encourage participants to review feelings, thoughts and daily behaviors in the context here and now; the counselor infers the assessment results; the counselor made an agreement with the respondent for the next meeting.

The SDBHSM card as the main equipment of treatment is a two-sided card (side A and B) containing six questions. Participants were asked to answer the six questions on the side A then the counselor explored each respondent's answers respectively from number 1 to 6 , the counselor confronted the respondent's answers so that the respondent came to full awareness 
by being given basic guidance service on the nature of human beings. The last session, participants were asked to answer six questions on the same card inside B to find the most essential and deep answers.

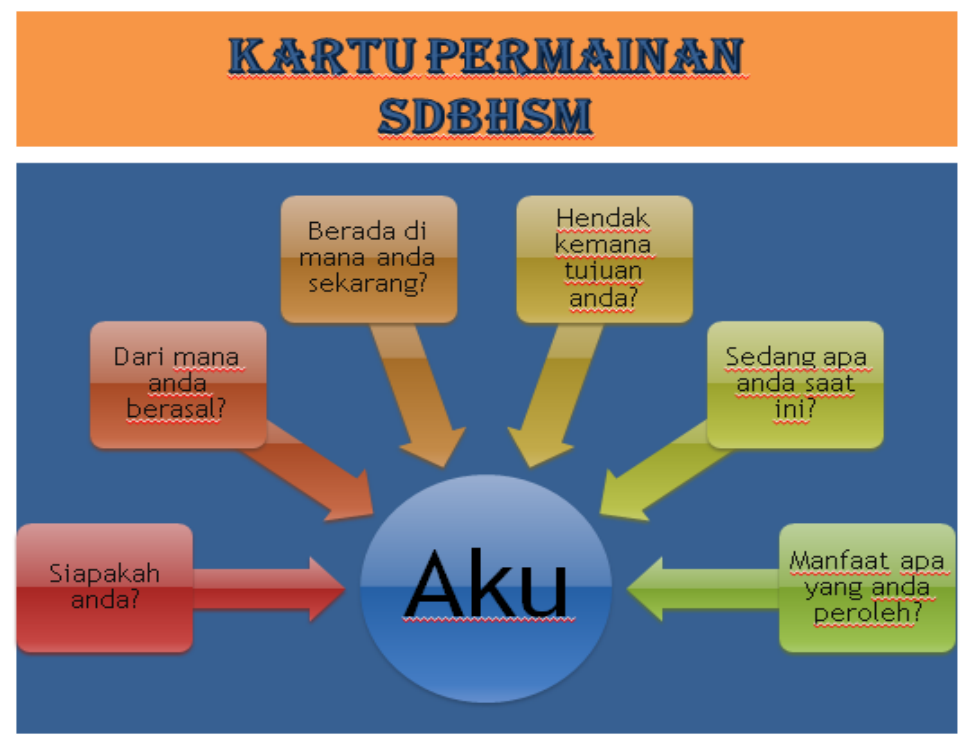

Figure 1. Side A of the SDBHSM (Rahman, 2018)
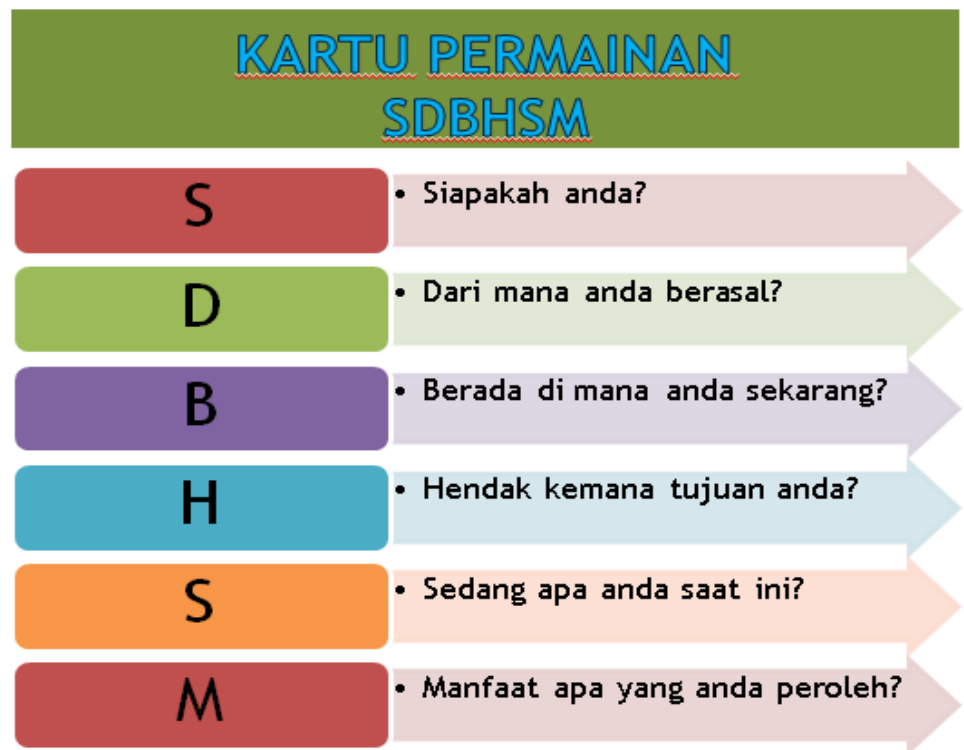

Figure 2. Side B of the SDBHSM (Rahman, 2018)

\section{The Responsive and Reflective Service}

This stage aims to help participants deal with and resolve problems related to parenting by indicating the uniqueness of important issues. These activities include: the implementation using two strategies, namely group guidance and individual counseling; establish techniques that are consistent with the uniqueness of the parenting problem; counselors need to consider to maintain the confidentiality code of ethics; in each meeting simply use one technique and examine the effectiveness of the technique to consider the use of other techniques at the next meeting in the same problem; Counselors and participants achieve full awareness of the dimensions of the inner zone, outer zone, and middle zone when starting each individual session. Counselors stated confrontational statements to participants in all sessions to encourage participants to review feelings, thoughts and daily behaviors in the context here 
and now; the counselor infers the assessment results; the counselor makes an agreement with the respondent for the next meeting.

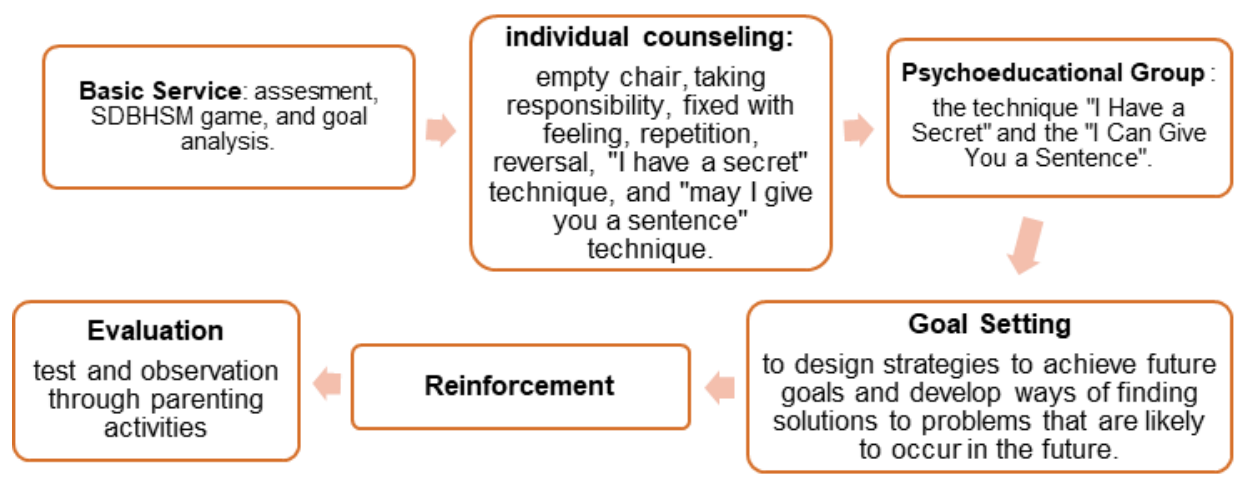

Figure 3. The Implementation of Experimental Study with G-Pro

\section{Integration Phase}

This stage aims to integrate the full awareness of the participants with various aspects of life, particularly the daily activities of participants. In addition, this service helps participants to exercise the courage to accept and acknowledge perceived and assertive obstacles by asking other participants for help in responding and giving input on the obstacles they feel and vice versa.

\section{Final Stage and Termination}

This stage aims to release participants from dependence on counselor assistance. This is done by giving reinforcement and confidence about the potential of participants that they are able to build better parenting for their children in preventive and curative actions on the use of gadgets.

\section{RESULTS AND DISCUSSION}

This study was conducted to help establish parenting method in raising a full parents awareness of their responsibilities as the first educator in the family in case of gadget addiction in early childhood with a Prophetic Gestalt approach. The results showed that there was a significant effect of the G-Pro on parenting for gadget addiction in early childhood.

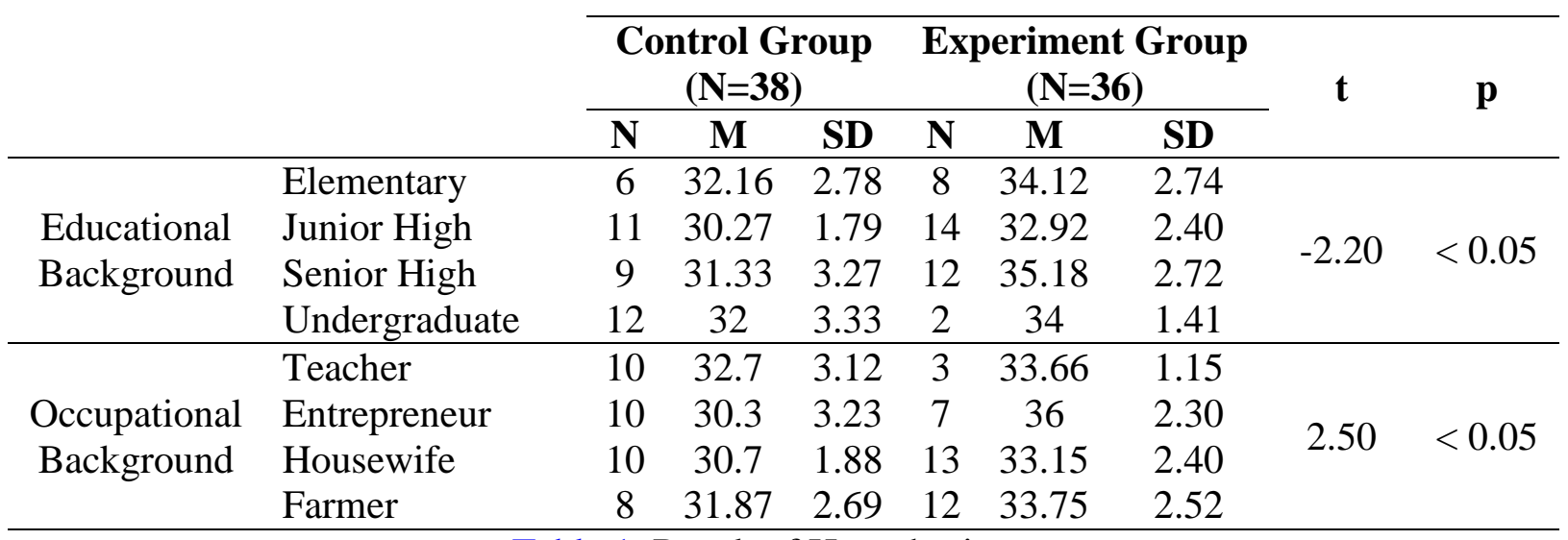

Table 1. Result of Hypothesis test

Participants involved in this study were 74 with 36 participants for the experimental group and 38 participants for the control group respectively. The educational and 
occupational background in the experimental group and the control group have presented in Table 1.

Based on Table 1, the control and experiment group have significant differences. The both educational $(\mathrm{t}=-2.20, \mathrm{p}=<0.05)$ and vocational $(\mathrm{t}=2.50, \mathrm{p}=<0.05)$ background showed difference mean and standard deviation. Which mean the hypothesis 1) there were differences in parenting between the group treated with Gestalt-Prophetic (G-Pro) and the group that was not treated. The mean between control and experiment group based on educational background showed the highest difference is senior high school and the lowest is an elementary school. Then, mean based on the occupational background the highest difference is entrepreneur and the lowest is teacher.

The education and occupation of parents influence the parenting process. This is in accordance with several statements that the high and low level of education of parents affects their parenting method. In addition, the economic status and occupation of parents greatly have an impact on children (Manurung, 1995; Santrock, 2014; Soekanto, 2004)

Gestalt-Prophetic (G-Pro) Approach is a reconstruction of Perls's Gestalt therapy in which there are various kinds of techniques that can explore themselves in order to understand themselves and their existence. In addition, Perls' Gestalt theory can also increase awareness and emphasis on self-support or self-responsibility. This is in accordance with the needs of couples of husbands and wives in raising awareness in providing good parenting method for gadgets use in children for their social and physical development.

The current parenting method for children is different from then (Faisal 2016). We can compare it with how our parents were successful in giving education and care to their children so that children become successful. However, the parenting method currently is more influenced by the globalization which a lot of technological sophistication, particularly gadgets. This is in accordance with Santrock statement, factors that influence the method of parenting, namely the existence of cultural changes such as values, norms, and customs that existed in the past and present (Santrock, 2014).

G-Pro proved to have a significant influence in building parenting awareness for gadget addiction in early childhood. This empirical evidence shows that the G-Pro approach can be implemented in developing parenting by raising individual awareness that is full of responsibility. The results also prove that parents' awareness in providing parenting for children with gadget addiction is very important. This supports the opinion of Desideria and Borba stating that some parents in a state of unconsciousness have given gadget to children as an equipment in providing care when parents are busy with personal, family, household, work, and community affairs and parents do not realize that children learn a lot by imitating the situation around them, including imitating their father and mother in using gadgets (Borba, 2010; Desideria, 2016; Palar et al., 2018). Velika also mentioned that today's parents often do not understand the dangers that can affect their children from these gadgets, they see the gadget only in terms of practicality (Velika, 2015).

The dialogue was used in its implementation of individual counseling. Participants (parents of early childhood) have the opportunity to experience conflict within themselves. The conflict can be in the form of busy on their duty; lack of knowledge or wrong model. Thus, the parents are expected to be able to realize and feel the conflict and be able to accept life. This study also supported the application of interactive communication assistance to children in using gadgets because of this method is certainly necessary to avoid negative impacts on its use (Musthafa, 2017; Warisyah, 2015).

The method of parenting by giving gadgets to children means reducing face to face time of parents and children. This is because the world of children has been controlled by the outside world. The children will be more vulnerable to external pressure and tend to rely on someone than their parents to guide and adopt stranger values. 
In the parenting stage, the first and second meeting the authors found majority of the respondents were able to instill the concept of full awareness of themselves as God's creatures who have the responsibility to provide education and teaching to children, having awareness of the side effects of using gadgets in long period of time that emerge the symptoms of addiction in children, as well as the importance for parents to obtain information about child development.

It is necessary to make changes in establishing parenting method for children, by changing parents principles, namely: 1) Learn how to behave properly. Some behavioral changes are influenced by biological factors. But behavior change can also begin with habits and learning. Although there are some things that cannot be changed, such as the personality and physical character of the child. But we can teach new habits, behaviors, values, and skills to the children can handle their world and overcome other physical problems. 2) Individual behavior change requires intervention. Children's behavior will not change by itself unless there is interference by their parents. 3) Changes are made by giving a more effective response to better results. When you willing to change your child's behavior then you must be able to change yourself first. The parent must be committed to using it. For instance, lower voice when something happened not accordingly and reward their good behavior, become closer physically, explain what you want clearly and directly, and expect properly as what asked. Finally, the parent must be able to be consistent. 4) Set one change at a time, focus on only one change so you or the child is not overwhelmed by trying it. So, the design of behavior changes can be more specific to eliminate bad behavior. 5) Train the children to settle with a new behavioral change. This aims for children to be able to use their former behavior confidently in real life without help. Finally, give reinforcement of the right actions for children.

The mean between control and experiment group based on educational background showed the highest difference is senior high school and the lowest is an elementary school. It is reasonable if the higher education parents have will increase the effectiveness of the G-Pro. Otherwise, the mean based on the occupational background the highest difference is entrepreneur and the lowest is teacher. It is also showed that even if someone has a profession as a teacher did not guarantee to have better when have to instill something new in their daily life.

Based on the findings above, the author provides a solution as an option in providing parenting method for children as well as parents able to distinguish the needs and desires, parents must also be able to pay attention to the security of using gadgets, agree to change, strengthen the rules for using gadgets. parents can have a good influence on children and look for positive activities.

Many factors support the acceptance of the hypothesis in this study, factors from were excluded from the training material, namely good delivery by counselors and respondents who are easily invited to work together. The respondents were enthusiastic about participating in this activity because it was the first experience for respondents.

The results of this study were expected to contribute as evidence based on references of counseling, particularly to establish parenting method. Supporting environmental conditions and cooperation from parents, schools, and communities will promote effective parenting for gadget addiction in early childhood.

\section{CONCLUSIONS}

Based on the result of the study, can be concluded that control and experiment group have significant differences after receiving treatment, it means G-Pro is effective to improve parent awareness on parenting method for early childhood with gadget addiction case. Both educational and vocational are also impact the effectiveness of G-Pro in improving parent 
awareness on parenting method for early childhood with gadget addiction case. The highest impact of G-Pro on the educational background is senior high school and the lowest is an elementary school. Then, the highest impact of G-Pro on the occupational background is entrepreneur and the lowest is teacher.

\section{ACKNOWLEDGMENTS}

The author expresses their sincere appreciation to the Ministry of Religion Affairs (MORA) of the Republic of Indonesia for research funding 2018. The acknowledgment also extended to everyone who contributed to this study.

\section{AUTHOR CONTRIBUTION STATEMENTS}

WK and SH designed the research and the instrument. NL and IA collected the data. WK, IA, NL, and SH conduct the experiment together. WK design the analysis and performed the analysis. All the author wrote the manuscript together and agree with the final version of the manuscript.

\section{REFERENCES}

Anna, L. K. (2018). Kesalahan Pola Asuh yang Sering Dilakukan Orangtua "Zaman Now." Retrieved from Kompas.com.

Baumrind, D. (2005). Patterns of parental authority and adolescent autonomy. New Directions for Child and Adolescent Development, 2005(108), 61-69. https://doi.org/10.1002/cd.128

Borba, Ed.D., M. (2010). The Big Book of Parenting Solutions: 101 Jawaban sekaligus Solusi bagi Kebingungan dan Kekhawatiran Orang tua dalam menghadapi Permasalahan Anak Sehari-hari. Jakarta: PT Elex Media Komputindo. Retrieved from Google Scholar

Brink, M. E. (2009). Gestalt guidelines assisting parents to enhance psychosocial development in children (Dissertation, University of South Africa). Retrieved from Google Scholar

Desideria, B. (2016). Mengapa Anak Jadi Ketagihan Gadget dan nonton TV? Retrieved from Liputan 6.

Djamarah, S. B. (2014). Pola Asuh Orang Tua dan Komunikasi dalam Keluarga. Jakarta: Rineka Cipta. Retrieved from Google Scholar

Faisal, N. (2016). Peran orang Tua dalam mendidika Anak di era Digital. An-Nisa', 9(2). 121137. Retrieved from Google Scholar

Fitriawati, U. H. D. (2019). Pengaruh konseling Gestalt Profetik terhadap tingkat self awareness dalam kebersihan lingkungan di Asrama Roudlotul Banin Wal Banat AlMasykuriyah Jemur Wonosari Surabaya (Undergraduate, UIN Sunan Ampel Surabaya). Retrieved from Google Scholar

Gunarsa, D. S. (2008). Psikologi Praktis: Anak, Remaja, dan Keluarga. Jakarta: PT. BPK Gunung Mulia. Retrieved from Google Scholar

Hartati, S. (2017). Konsep Spiritual Parenting dengan Pendekatan Konseling Behavioristik dalam Membentuk Moral Anak Usia Sekolah Dasar. Bina Gogik: Jurnal Ilmiah Pendidikan Guru Sekolah Dasar, 4(1). Retrieved from Google Scholar 
Hartati, S., Latipah, E., \& Maba, A. P. (2018). Penurunan perilaku seksual pranikah melalui Tazkiyatun Nafs berbasis REBT. Counsellia: Jurnal Bimbingan Dan Konseling, 8(2), 122-134. https://doi.org/10.25273/counsellia.v8i2.3038

Jannah, H. (2012). Bentuk Pola Asuh Orang Tua dalam Menanamkan Perilaku Moral pada Anak Usia di Kecamatan Ampek Angkek. Pesona PAUD, 1(1). Retrieved from Google Scholar

King, L. A. (2010). Psikologi Umum: Sebuah Pandangan Apresiatif. Jakarta: Salemba Humanika. Retrieved from Google Scholar

Komalasari, G. (2014). Teori dan Teknik Konseling. Jakarta: PT Indeks. Retrieved from Google Scholar

Manurung. (1995). Manajemen Keluarga. Bandung: Indonesia Publishing House. Retrieved from Google Scholar

Musthafa, F. A. D. (2017). Upaya Mengatasi Kecanduan Anak Terhadap Gawai (Gadget) Melalui Model Komunikasi Interaktif Orang Tua dan Anak Berdasar Al-Quran. Proceedings Ancoms 2017 (Annual Conference for Muslim Scholars) Kopertais Wilayah IV Surabaya. Retrieved from Google Scholar

Palar, J. E., Onibala, F., \& Oroh, W. (2018). Hubungan Peran Keluarga dalam Menghindari Dampak Negatif Penggunaan Gadget Pada Anak Dengan Perilaku Anak dalam Penggunaan Gadget Di Desa Kiawa 2 Barat Kecamatan Kawangkoan Utara. E-journal Keperawatan (E-Kp), 6(2), 1-8. Retrieved from Google Scholar

Rahman, I. K. (2017). Gestalt Profetik (G-PRO) Best Practice Pendekatan Bimbingan Dan Konseling Sufistik. KONSELING RELIGI: Jurnal Bimbingan Konseling Islam, 8(1),151-172. https://doi.org/10.21043/kr.v8i1.2216

Rahman, I. K. (2018). Bimbingan dan Konseling Gestalt Profetik (Konsep, Praktik Bimbingan dan Konseling Islami). Bogor: UIKA Press.

Santoso, L. E. C., Bramantijo, \& Sutanto, R. P. (2013). Perancangan Kampanye Sosial bagi Orang Tua Tentang Bahaya Tablet PC bagi Anak Usia 2 Tahun ke Bawah. Jurnal DKV Adiwarna, 1(2), 1-11. Retrieved from Google Scholar

Santrock, J. W. (2014). Essentials of life-span development. New York, NY: McGraw-Hill. Retrieved from Google Scholar

Setianingsih, Ardani, A. W., \& Khayati, F. N. (2018). Dampak Pengggunaan Gadget pada Anak Usia Prasekolah dapat Meningkatkan Resiko Gangguan Pemusatan Perhatian dan Hiperaktivitas. GASTER, 16(2). Retrieved from Google Scholar

Soekanto, S. (2004). Sosiologi Keluarga tentang Ikhwal Keluarga, Remaja dan Anak. Jakarta: Rineka Cipta. Retrieved from Google Scholar

Sunarti, E. (2004). Mengasuh Anak Deangan Hati. Jakarta: PT Elex Media Komputindo. Retrieved from Google Scholar

Trijayanti, Y. W., Nurihsan, J., \& Hafina, A. (2019). Gestalt Counseling with Empty Chair Technique to Reduce Guilt among Adolescents at Risk. Islamic Guidance and Counseling Journal, 2(1), 1-10. https://doi.org/10.25217/igcj.v2i1.302

Velika, V. (2015). Perancangan Iklan Layanan Masyarakat Penggunaan Gadget Bijaksana Pada Anak Usia 3-5 Tahun Di Surabaya. Jurnal DKV Adiwarna, 1(6), 1-11. Retrieved from Google Scholar 
Warisyah, Y. (2015). Pentingnya "Pendampingan Dialogis" Orang Tua dalam Penggunaan Gadget pada Anak Usia Dini. Prosiding Seminar Nasional Pendidikan. Inovasi Pembelajaran untuk Pendidikan Berkemajuan, FKIP Universitas Muhammadiyah Ponorogo. Retrieved from Google Scholar

Wijayanti, R., \& Akbar, M. R. (2018). Asesment Model Strategi Coping Orangtua Murid untuk Permasalahan Anak Usia Dini. JIP: Jurnal Inspirasi Pendidikan, 8(1), 79-83. https://doi.org/10.21067/jip.v8i1.2246

Wulandari, F. C., \& Ristiawanti. (2018). Hubungan Tipe Pola Asuh Orang Tua dengan Kebebasan Penggunaan Gadget pada Anak di SD Negeri Burat Kecamatan Kepil Kabupaten Wonosobo. Jurnal Komunikasi Kesehatan, 9(2), 18-28. Retrieved from Google Scholar 